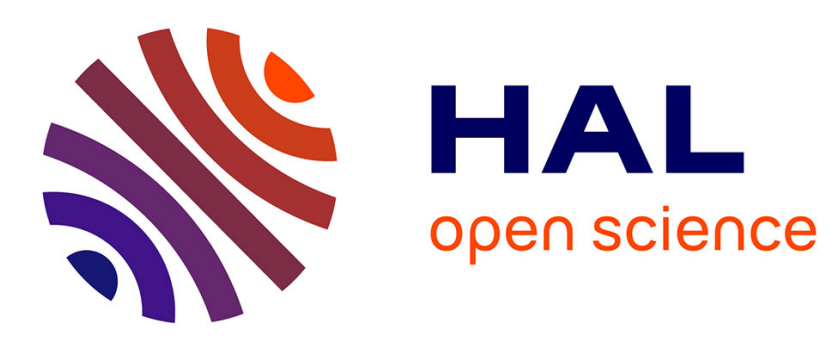

\title{
Opposition to the forensic use of DNA in France: the jurisdiction and veridiction effects
}

Joëlle Vailly, Yasmine Bouagga

\section{To cite this version:}

Joëlle Vailly, Yasmine Bouagga. Opposition to the forensic use of DNA in France: the jurisdiction and veridiction effects. BioSocieties, 2019, 15 (3), pp.394-419. 10.1057/s41292-019-00150-y . halshs02132130

\section{HAL Id: halshs-02132130 \\ https://shs.hal.science/halshs-02132130}

Submitted on 9 Oct 2020

HAL is a multi-disciplinary open access archive for the deposit and dissemination of scientific research documents, whether they are published or not. The documents may come from teaching and research institutions in France or abroad, or from public or private research centers.
L'archive ouverte pluridisciplinaire HAL, est destinée au dépôt et à la diffusion de documents scientifiques de niveau recherche, publiés ou non, émanant des établissements d'enseignement et de recherche français ou étrangers, des laboratoires publics ou privés. 
Vailly, J., Bouagga, Y. (2019). Opposition to the Forensic Use of DNA in France: The Jurisdiction and Veridiction Effects, BioSocieties, 15 (3), 349-419. On line May 3, 2019.

\section{Opposition to the Forensic Use of DNA in France: The Jurisdiction and Veridiction Effects}

Joëlle Vailly*

CNRS, Institut de recherche interdisciplinaire sur les enjeux sociaux (Iris, CNRS, Inserm, EHESS, Université Paris 13), Paris, France.

vailly@ehess.fr

Yasmine Bouagga

Laboratoire Triangle (ENS), Lyon, France.

yasmine.bouagga@ens-lyon.fr

* Corresponding author

\section{About the authors}

Joëlle Vailly is an anthropologist and a sociologist. She is a Research Director at the Centre National de la Recherche Scientifique (Scientific Research National Center, CNRS), in France. Her research interests concern social, political, and moral issues in genetics, biomedicine, and health.

Yasmine Bouagga is a sociologist. She is a Research fellow at the Centre National de la Recherche Scientifique (CNRS), in France. Her research interests concern sociology of law and political anthropology. 


\begin{abstract}
The use of genetic databases by the police and justice system has risen dramatically over the last twenty years, particularly in France, which has the second largest database in Europe. In such a context, this article analyses the legal and scientific effects of the forensic use of DNA on the formation of individuals' (bio)identities in France. More specifically, we adopt a line of investigation that builds out from forms of resistance to genetic databases. Our methodology draws on a series of interviews and observations of legal proceedings against people who have refused to give DNA samples. In the first part of this text, we focus on the 'jurisdiction effects' of the DNA database being expanded to populations, showing that legal classifications (offender, suspect, etc.) constitute a key issue for these opponents. We then go on to analyse the 'veridiction effects' at work among social actors, in terms of the medical information/information related to origin that is conveyed (or not) by DNA profiles. In conclusion, we show that genetic analyses applied in a criminal context to populations, rather than simply individuals, shift (bio)identities through these dual effects, which form the basis of opponents' resistance to genetic databases.
\end{abstract}

Keywords: genetics, forensics, resistance, identity, anthropology, France 
Preamble: A group of activists who were opposed to the excessive use of advertising billboards 'tagged' such billboards in a downtown area in northern France. They were caught in the act and charged with 'vandalism or minor damage of property with an inscription, symbol or drawing,' a misdemeanour covered by the scope of the French national DNA database. The group did not deny their actions and-as activists-even claimed them, although they preferred the term 'scribbling' rather than vandalism; but they refused to give a DNA sample. At the end of the trial for these two offences, they were acquitted of the vandalism charge, but fined 500 euros with a suspended sentence for refusing a DNA sample. In a broader sense, some opponents of DNA sampling have been convicted several times for their refusals, because the request for their DNA was reiterated: if individuals have been convicted once for the crime, this does not prevent them from being convicted again for a new refusal. This example gives us an initial insight into the topic of genetic databases expanded to populations, arguments for refusing to be included in such a database, and the effects revealed by these arguments.

Although the rationale of filing is an old one in France (Mattelard and Vitalis, 2014), its development is more recent, as seen in the way populations have been put on file in the case of a series of police databases, such as the Traitement d'Antécédents Judiciaires (TAJ), the Fichier automatisé des empreintes digitales (FAED) and the Fichier national automatisé des empreintes génétiques (FNAEG). ${ }^{\mathrm{i}}$ This latter, created in 1998, was initially restricted to sex offenders. The so-called law on daily security (loi de sécurité quotidienne) of 2001 extended its scope to include all crimes against the person. With the law on internal security (loi de sécurité intérieure) of 2003 this was further extended to property crimes (both felonies and misdemeanours covering attempted murder, torture and barbaric acts and assault; theft, extortion, fraud, damage, vandalism and threat to property), or in other words the majority of offences included in the French Penal Code except those regarding the rights of foreigners and involuntary offences against the person (involuntary manslaughter and injury). ${ }^{\mathrm{ii}}$ This expansion of the number of crimes covered by legislation has been compounded by the fact that the FNAEG includes not only the data of convicted individuals but also of those who have only been suspected of an offence and who are, according to French law, presumed innocent. ${ }^{\text {iii }}$ Individuals who have been suspected but not convicted of an offence represent around $75 \%$ of the profiles in the FNAEG. ${ }^{\text {iv }}$ Minors over the age of 13 may be subject to having their DNA profile included in the database. ${ }^{\mathrm{v}}$ In parallel, the laws of 2001 and 2003 legalised sanctions for the refusal to give a DNA sample, in the case of those convicted (2001) 
as well as suspected individuals (2003). This explains how, by spring 2018, the FNAEG included 3.8 million individual DNA profiles, along with a further half a million unidentified profiles from traces left behind at crime scenes or from anonymous corpses. The first of these figures does not however take into account any 'duplicates' in the database, the result of individual profiles being registered under different names. ${ }^{\text {vi }}$ In October 2018 a report estimated there to be around 2.9 million individual genetic profiles, after removing duplicates, and 480,000 unidentified traces in the FNAEG. ${ }^{\text {vii }}$ DNA profiles stored in the FNAEG are retained for 25 years in the case of suspects and for 40 years for convicted individuals. This time period applies to all individuals whether they are minors or adults, and regardless of the seriousness of the offence concerned. As per the law of 2003, the DNA samples of identified individuals must be destroyed, although the laboratory may retain part of the person's file for subsequent examination. DNA profiles of suspects can be removed from the FNAEG upon the instruction of the Public Prosecutor (Procureur de la République) acting either exofficio - which is very rarely the case — or at the request of the individual concerned if the retention of a file is no longer required for the purposes of the database ("lorsque la conservation [des données] n'apparaît plus nécessaire compte tenu de la finalité du fichier"). ${ }^{\text {viii }}$ In 2015, the number of individual profiles removed from the FNAEG for these reasons was very low, at around only 160 per year. ${ }^{\text {ix }}$ In short, use of the database is both widescale and routine, in terms of the number of genetic profiles it includes and the types of offences covered (not only felonies, which occur infrequently, but also burglary, theft, vandalism etc. which are much more common); and in addition the data is retained for a long period of time.

French law further stipulates that the tests used to take DNA profiles must be based on markers located in 'non-coding' DNA. ${ }^{\mathrm{x}}$ Non-coding DNA, which constitutes $90-95 \%$ of human DNA, by definition does not directly contribute to the synthesis of proteins and is meant to hold no other information than an individual's identity, in the manner of fingerprints. Such non-coding DNA thus provides a robust, non-modifiable and incorporated form of 'primary identity' (Jenkins, 2000, p. 14), here founded on 'genetic markers' (short sequences of DNA). ${ }^{\mathrm{x}}$ The significance of this issue will be discussed later.

From an analytical point of view, Koch and Stemerding (1994) suggest the term 'regime' for technological, organisational and societal practices resulting from earlier processes of 'attunement,' which include technological options, professional demands and social 
acceptability. In France, the procedure established for taking DNA samples from sex offenders facilitated the acceptability and legality of wider use of the database, based on the same type of technological organisation and social interaction. We would highlight that there are notably some remaining restrictions on the extension of the scope of the FNAEG, since economic and financial crimes (insider trading, fiscal fraud, misuse of company property, etc.) are not covered, although serious fraud, money laundering, and concealment do fall within the scope. There is therefore a 'system of differentiations which permits one to act upon the actions of others: differentiations determined by the law or by traditions of status and privilege' between types of offence which is the result of power relations (Foucault, 1982, p. 223).

These database procedures and refusals to provide DNA produce effects in which classification ('vandalism,' in the example above, etc.) plays an important role. In effect, through the intermediary of language, this establishes not just descriptions, but also legal qualifications and classifications ('convicted for refusing to provide a sample,' 'arrested,' etc.). Classifications that in turn affect the individuals classified and, as such, contribute to 'making up people' (Hacking, 2005) who may express resistance to these classifications. In other words, the process of labelling has social and individual consequences, just as genetics play a role in producing identities by (re)creating categories of difference and belonging (Schramm, Skinner and Rottenburg, 2012). Thus, following life sciences anthropology, the questions posed in this article can be formulated as follows. From the point of view of the opponents of genetic databases, what roles do the uses made of DNA in a policing and legal context, as described above, play in transforming the identities attributed to or claimed by individuals? How does this transformation relate to the effects contested by these opponents in the legal and scientific spheres?

In a well-known study, Rabinow (1996) predicted the probable development of new identities and individual and collective practices based on genetic knowledge. He analysed the development of patient groups who have become experts on their disease. These groups form around the collective identities of predisposition to genetic disease, termed 'bio-identities.' He believed that older cultural classifications (such as gender, race and age) would be joined by a wide range of new classifications that would intersect with, partly transcend and ultimately redefine these old categories. Since then, Rabinow and his colleagues have moved away from the medical sphere towards studying 'what forms of political analysis, moral reflection and 
techno-scientific practice are being mobilized by actors (scientists, policy makers, planners) in shaping - and operating in relationship to - something called biosecurity' (Collier, Lakoff and Rabinow, 2004, p. 5). As observed by Keck (2010), the focus appears to have moved from one kind of bio-identity - medical - to another, more unexpected kind: from that of a disease expert to that of a suspect, or even guilty individual.

This requires further analysis, since when considered more closely, the term bio-identity may have several meanings. Ricœur (1990) makes a distinction between two primary meanings of identity, depending on whether the term is used to refer to 'sameness,' the equivalent of idem, used in the context of comparison (for example, in the statement: 'Two molecules are identical'), or to 'selfhood,' the equivalent of the Latin ipse, used in the context of characterisation (for example in the statement: 'This individual has many identities'). As will be seen in this article, such distinctions are highly illuminating in the case of DNA, which is both a chemical molecule and a vector of social identity. It should be noted however that while Ricœur solely discusses the identity of the 'self' as a rational, expressive subject considered from within, here we also consider the 'other' as it is classified and seen from the outside. Unlike Ricœur and, indeed, Rabinow, we are equally interested in both the 'I' or 'we' (the expressive subject, the patient) and the plural or singular 'you' (the perpetrator, the suspect), or in other words, following Jenkins (2000), equally interested in the 'group' to which members acknowledge they belong and the 'category' attributed to the 'other' that emerges from social practices linked to a form of knowledge/power.

Studies on the acceptability of genetics show that, in the UK, most members of the general public see the use of DNA in forensics 'as the least controversial and most beneficial of genetics applications' (Wilson-Kovacs, Wyatt and Hauskeller, 2012, p. 288); that, in New Zealand and Serbia, there is a public acceptance of methods seeking to identify criminals and strengthen prosecutions (Veth and Midgley, 2010; Curtis, 2014; Teodorovic et al., 2017); and that, in Portugal, 'an acknowledgement of the investigative potential of forensic DNA technologies and a relegation of civil liberties and human rights to the background, owing to the perceived benefits of protecting both society and the individual from crime,' has been observed (Machado and Silva, 2014, p. 132). This has not prevented the rise of some opposition based on the arguments of human rights violations and the development of the surveillance society (Etzioni, 2004), questions being raised concerning public freedoms and the misuse of genetics (Machado and Silva, 2014; Teodorovic et al., 2017), particularly in the 
media (Hindmarsh, 2010), or concerns expressed in an ethico-legal context (Guillen et al., 2000; Gamero et al., 2004). In short, although the public reception of these practices initially appears to be positive, more critical questioning may be apparent when points of view are examined more closely (Curtis, 2014), particularly in the activist and charity sectors (Williams and Wienroth, 2014a; 2017). However, on the whole, these different studies have not necessarily included an analysis of the issues and discourse at the level of opponents to the use of DNA databases. Nor do they take an interest in the political effects of extending databases to populations. Our approach will focus more closely on political forms, including citizen action, than on the institutional and judicial context. This means privileging a mode of investigation that takes its departure from forms of resistance to different kinds of power and '[uses] this resistance as a chemical catalyst' (Foucault, 1982, p. 211) to reveal the contested social effects of genetic databases. Unlike other studies in which it has not been the object, this will enable us to develop an in-depth analysis of (bio)identities, the effects produced and the power relationships at stake. This is also the first study within the social sciences to look at the use of the DNA database in France, which is the second largest in Europe after that of the United Kingdom.

In the first part of the text, we analyse the 'jurisdiction effects' (Foucault 2001[1994]a, p. 841) of genetic databases. We show that opponents of the expanded use of genetic databases rely on a form of mobilisation that claims to be civic in nature, within the broader context of power relationships that favour the databases. These opponents do not contest the specific use of DNA in the context of comparisons enabling matches between two genetic profiles, in the register of sameness (Ricœur, 1992). However, they appear to oppose the move from this type of use to a use extended to whole populations that transforms the bio-identity of individuals in the database by assimilating them with long-term suspects and criminals, in the register of selfhood. We then demonstrate the 'veridiction effects' (Foucault 2001[1994]a, p. 841) in terms of the medical information or information related to origin that is conveyed, according to these opponents, by DNA profiles. We show how these scientific arguments strengthen their point of view: again, the identity of individuals included in the database appears to surpass the context of comparison with DNA profiles (in the register of sameness) and extend towards characterising people (based on their predisposition to a disease or their origin, in the register of selfhood), but here on the basis of scientific arguments. Furthermore, these opponents seek to introduce a form of citizen control on the link between genetic technology and the potential biopolitical use of identity, in a context in which the files kept on Jewish 
populations during World War II in France and the electoral success of the extreme right as a possible indicator of the country's future both weigh heavily on their point of view. In conclusion, our study shows that genetic analyses applied in a criminal context to populations, rather than simply individuals, shift (bio)identities through these dual jurisdiction/veridiction effects, which form the basis of opponents' resistance to genetic databases.

\section{Study Outline}

This study is part of a much wider project looking at the social issues surrounding the genetic analyses used by the judiciary and the police in France (Vailly et al., 2016). This text is concerned with the political challenges surrounding the FNAEG. ${ }^{\text {xii }}$ It will not therefore consider individual refusals to provide a sample on the grounds of common law (burglary, drug trafficking, etc.), which would require another type of study, as they are few in number and lack visibility since they are not publicised. In order to carry out our investigation, in 2015 and 2016 we held 17 semi-structured interviews with various heads of organisations and trade unions (two magistrates trade unions, the Union Syndicale des Magistrats and the Syndicat de la Magistrature; the lawyers' trade union Syndicat des Avocats de France, and the Human Rights League of France, the Ligue des Droits de l'Homme; $\mathrm{N}=6$ ) and activists who had refused to give DNA samples and their lawyers $(\mathrm{N}=11)$. With a view to shedding light on opponents' statements and providing statistical data, we also conducted 4 collective interviews including members of the project team (cf. Acknowledgements) with representatives from the forensic science police services $(\mathrm{N}=2)$, gendarmes $(\mathrm{N}=1)$ and a senior civil servant and magistrate $(\mathrm{N}=1)$. We also observed legal proceedings across France against individuals who had refused to give DNA samples $(\mathrm{N}=7)$. All interviews and observations were coded using NVivo data analysis software, with a particular focus on the effects of databases. Finally, numerous documents were collected and analysed in the course of our interviews, including judicial decisions, ministerial circulars, leaflets, and information brochures. A common method for qualitative surveys was applied that consists in adjusting analysis as investigations go forward (Glaser and Strauss, 1967). The study protocol relating to the methods for collecting and analyzing the data and for ensuring anonymity, confidentiality, and privacy was approved by the French National Research Agency (a French public agency) and complied with the regulations of the ethical guidelines of the European Association of Social Anthropologists and the American Anthropological Association. 


\section{Jurisdiction Effects}

In the first part, we will analyse the 'jurisdiction effects' (Foucault, 2001[1994]a, p. 841), or in other words the effects on production and implementation of the law, in regard to these practices applied to populations.

\section{The Effects of Genetic Databases on the Definition of Offenders vs. Citizens}

The so-called 'daily security' and 'internal security' laws, as we have seen, made it an offence to refuse to give a DNA sample. ${ }^{\text {xii }}$ Circulars from the Ministry for Justice, which stand uncontradicted to date, state that: 'Refusals to provide a DNA sample on the part of arrested or convicted individuals should be systematically pursued. ${ }^{\text {xiv }}$ This systematic pursuit allows for an estimation of the number of refusals to give a sample, since the number of convictions for such refusals oscillates between 382 in 2005 and 542 in 2013, with a peak of 604 in $2008 .{ }^{\mathrm{xv}}$ One of the groups of activists at the forefront of resistance to the FNAEG has been a collectively organised group of Genetically Modified Organisms (GMOs) protesters. Following an internal debate about whether or not to agree to give a DNA sample, a majority of the group decided to refuse. But the creation in 2008 of a specific crime for the destruction of GM crops, not covered under the scope of the FNAEG, meant that GMO protesters were no longer concerned (we note that convictions for refusing to provide a sample also peaked in 2008). This is sometimes seen as a way for the authorities to circumvent opposition, as one police officer suggested in an interview: 'Now they're no longer in the database, everyone's happy, it's not a problem anymore.' Beyond the GMO crop pickers, public opposition to the FNAEG has been led primarily by political and union activists, who constitute a network of relative shared knowledge within union, environmental, and/or anarchist circles. Importantly, they have received professional support, notably from lawyers and magistrates from the membership of the magistrate union the Syndicat de la Magistrature (SM), the second largest judiciary trade union in France, the lawyers' union the Syndicat des Avocats de France (SAF) and the human rights association Ligue des droits de l'Homme (LDH), three organisations that are situated on the political left and are at the forefront of the defence of civil liberties. With a view to going even beyond these collectives, these opponents seek media exposure in order to widen the impact of their actions, wishing in effect to use legal proceedings as a forum for advancing their cause and creating a public debate, and some of these trials have indeed received coverage by the media. Their trials thus take on a tribunician function, with the aim 
of constructing social problem within an arena that is both judicial and newsworthy (Bonneuil, Joly and Marris, 2008).

Opponents look to achieve greater publicity for their cause because resistance to the extensive use of taking and retaining DNA samples is not commonplace in France. As indicated in our interview with a lawyer defending political activists: 'It's clear that French society sees the FNAEG as an excellent method of surveillance ... We've always had difficulty criticizing the system.' Interviewees presented a whole host of reasons that might lead people to agree to give a DNA sample: lack of awareness that it is possible to refuse, fear of a more serious sentence or of being held for longer under arrest in sometimes oppressing conditions, the cost of legal fees incurred by legal proceedings against a refusal, the framework of the FNAEG consultation procedures, the relatively 'painless' nature of the database-which cannot be consulted by employers and is thus 'forgotten'-, or its banalisation among other database uses. According to Mattelart and Vitalis (2014, p. 194), 'it is precisely in this invisibility in which a large part of the power and efficacy' of databases resides. ${ }^{\text {xvi }}$

These opponents are however extremely troubled by the significant development of databases for police and judicial purposes, and in particular that of the FNAEG, which they consider to be at risk of infringing personal liberties. It is worth noting that in October 2018, a factfinding committee for the French National Assembly published a report listing 106 databases available to the security forces (police and gendarmerie), all types of police and legal databases combined. This report highlighted that these databases 'are too many in number and form an overly complex whole', while further calling for them to be rationalised, digitised, and connected, rather than for database use to be limited (Rapport d'information sur les fichiers mis à la disposition des forces de sécurité, p. 20). Importantly, it should be noted that opposition to the FNAEG has not concerned the use of DNA material in criminal justice as a whole, i.e. the principle of comparing traces of DNA with those of a suspect identified by standard investigatory means, or even the use of the database for serious crimes (murder, rape, etc.), but has rather centred around certain extensive uses of the database regarding the individuals and kinds of crime included, and the length of time for which DNA information is retained. In other words, it seeks to disassociate the use of genetic databases extended to populations from the use of genetics to compare traces of DNA with that of a suspect identified as part of a case, or the DNA of an anonymous corpse with that of a possible relative. One activist lawyer explains in an interview: 
There's a big difference between asking this or that well-targeted individual to give his or her DNA to check compatibility with the DNA found at the scene of a crime, and putting millions of people in a database ... I mean it's like suspecting these millions of French people of being possible offenders.

One opponent to FNAEG insists:

It's no longer a database used to find information in the context of specific cases, but really a database of potentially dangerous individuals.

It is the jurisdiction effects of the use of genetic databases that are challenged here (should millions of people be in the database? who is under suspicion? who is an offender?). And yet, while the legal definitions used during proceedings make no distinction between common law offences and those of a union action, political, or community nature, these opponents certainly do not see themselves as criminals. As one explained in their interview:

[DNA sampling] should be reserved for criminals who are actually potentially dangerous. Trade unionists and community activists acting within the framework of their union mandates are not criminals... . This is completely different from the idea of individual, heinous criminal acts with the idea of causing harm to others. We're actually [acting] in the interest of collective defence, in the general interest of employees.

There is a moral dimension here in the refusal to be assimilated with offenders, a sense of honour coming under attack. It is worth noting that this distancing of oneself from criminals has been observed in other countries, such as Portugal (Machado and Silva, 2014; 2016). When they defend the idea that $I$ am not a sex offender, so I should not be in the same database as rapists, they point to another concept. The demand for individual and collective rights (the right of this or that individual or group of individuals not to be included in the database) correlates to the production of a collective alterity that can be included in the database because it is made up of 'real' criminals. This position of alterity can be situated within the broader history of the labour movement. According to Foucault (2001 [1994]b), during the nineteenth century, in order to escape police repression and accusations that their organisations consisted of murderers, thieves and alcoholics, labour movements and their leaders were compelled to set themselves apart from the criminal population. In his view, this resulted in their endorsement of the separation of common law prisoners from political prisoners in more recent times. 
However, this last point of view is not shared by all opponents. To provide an example, a magistrate from the Syndicat de la Magistrature union involved in supporting opponents explains in an interview:

It would be troubling and counterproductive to make a distinction between the good people, those who are included in the database for taking part in a political demonstration, for example, and should be excluded, and those who are less defensible, people like young delinquent ... It would be damaging to restrict ourselves to the niche group of political and union activists.

According to this second position, merely affirming that union activists should not enter the database does not enable acknowledgement of the scope of the problem: the extension of FNAEG and the length of time for which data is retained.

Not only do these opponents not consider themselves to be criminals, but they see themselves as defenders of causes in the public interest: 'We're actually acting in the interest of collective defence, in the general interest of employees,' one explained in our interview. In this spirit, during a trial for refusing a DNA sample, the lawyer for an anti-advertising protestor declared that:

These people are whistleblowers (lanceurs d'alerte), citizens openly delivering a message, citizens who are alerting us. ${ }^{\text {xvii }}$

Some activists we interviewed even saw themselves as makers of the law, committing an act against the law in order to change it (e.g. to give industrial action immunity from criminal prosecution, or limit the use of advertising billboards). An individual who had destroyed GM crops thus stated in our interview:

I reject the offender label because I was acting as a citizen, and I did it [destroyed GM crops] so that the law would change, so the law would be recognised. I think there is the possibility for citizens that, by acting on the legal system, judges will take measures that will later drive changes to the law through precedent.

These statements require closer analysis. Firstly, given the statements from opponents ('We've always had difficulty criticizing the system') and the relatively limited number of individuals refusing to give a DNA sample, the use of genetic databases represents a form of power with consent from the majority of the population: the French population, as a whole, consents to the type of power represented by the extension of genetic databases beyond individuals. This persists not by being imposed, but by being generally accepted. In a general 
manner, as described earlier, the majority acceptance of genetic databases is observed in various other countries, even if it does not prevent certain forms of opposition. Populations are increasingly accepting genetic profiling, the universal surveillance of cameras in public spaces, and digital surveillance through computer technologies, etc. (Lianos, 2003; Marx, 2015).

Secondly, opposition to the use of databases, and in particular genetic databases, is linked to their extensive use and expansion to the population level. Opposition is not expressed in relation to specific comparisons between an individual suspected as part of a standard investigation and a trace left behind at a crime scene. As a result, jurisdiction effects arising from legal and police classifications (convicted of a crime, suspect, etc.) constitute a key issue for opponents. They refuse to be assimilated with a suspected or criminal population, or in other words a population associated with 'risk management' (Castel, 1981), here representing a danger for other people. They do not believe they should be part of what some authors describe as a 'social triage' (Aas, 2006) capable of sifting out populations at high-risk and low-risk of committing offences. ${ }^{\text {xvii }}$ To return to our theoretical framework, they do not contest the specific use of DNA in the comparison of DNA profiles enabling matches between two identical genetic profiles, in the register of sameness (Ricœur, 1992). However, they appear to oppose the move from this type of use to a form of use extended to whole populations that transforms the bio-identity of individuals in the database, who are assimilated with long-term suspects or criminals, in the register of selfhood ('it's like suspecting these millions of French people of being possible offenders'). Here, opposition is expressed in relation to the transformation of the selfhood of individuals (who may pass from the status of innocent to that of suspect or guilty individual, according to our interviewees), rather than their sameness (which stems from the specific comparison of genetic markers).

Thirdly, far from considering themselves to be 'criminals,' these activists see themselves as 'legal entrepreneurs' advancing laws, to paraphrase Becker (1973). They are not isolated individuals, but constitute a network of shared knowledge and see themselves as a citizens' collective. Their position provides a way to analyse more closely the concept of 'biological citizenship' (Petryna, 2002; Rose, 2007), which has been discussed in the field of health and life social sciences. ${ }^{\mathrm{xix}}$ Broadening out this concept by taking it beyond the context of medicine and health, various authors have substantially moulded the concept to apply in the case of suspects whose information is included in DNA databases run by the state: 'If we think of this 
[the DNA databases] as a form of "genetic citizenship" or "biological citizenship" then it clearly has different features than the celebrated case of the self-organizing citizens who form support and advocacy organizations, for whom biological knowledge is a source of their selfidentification. This is not about self-definition but definition by the state' (Tutton and Levitt, 2010, p. 97-98; see also Heinemann and Lemke, 2014). Our situation is different again, since the definition of citizenship produced here is not only produced by the state (through genetic identification) but also by the actors themselves (through collective action). Although we will later see how the truly biological aspect of the debate may also come into play, the citizenship produced, at least initially, is set against biological citizenship, precisely because these opponents reject the 'biological' or 'bio' aspect of bio-identity. To take up a distinction proposed by Agamben (1998), it is not so much from the point of view of zoe, of 'bare life' or the simple fact of living, that they claim their position, but rather of bios, of being actors in 'political life' and organising themselves collectively. Or quite simply as citizens, if we consider that the term 'citizen' refers to the idea of individuals fully engaged in public activities and/or whose rights are recognised. Unlike situations in which the individuals considered to be 'good citizens' by those who run genetic databases are those who provide their DNA willingly (Machado and Silva, 2009; 2016), here the opponents who refuse to provide their DNA claim to be full citizens ('I was acting as a citizen'). In an echo of the extended use of databases, these activists define a political form of citizenship that is collectively organised and aims to influence the boundaries of the powers of the state over individuals.

\section{The Argument of Proportionality and Right to Private Life}

As indicated by the use of legal proceedings to plead their case, public opposition to genetic databases by the activists is underlined by the arguments mobilised in legal battles. The condemnation of the database as an increasingly 'penal' element of the state, in the eyes of its opponents, raises political and moral questions that translate into legal terms via the principle of proportionality. GMO protesters adopted this argument early on in the course of legal proceedings against their refusals to give samples, and this argument is now mobilised to legally challenge the FNAEG. More precisely, the principle may refer to the disproportionate infringement of rights compared to the benign nature of the offence concerned, even if, as seen in the opening example, the way in which offences are classified can make them more serious ('vandalism' for tagging, etc.). But it can also refer to the methods of arrest, or to the 
handling of the DNA samples provided, in terms of the rather lengthy time period they are retained, or of their deletion, or the link to private life. This argument of proportionality with regard to the intrusion into private life hinges on article 8 of the European Convention of Human Rights, according to which 'everyone has the right to respect for his private and family life, his home and his correspondence,' and is supported by lawyers and defendants with European case law through the example of $S$. and Marper $v$ United Kingdom, decided by the European Court of Human Rights (ECHR). ${ }^{\mathrm{xx}}$ This decision had a major impact, leading to the United Kingdom destroying 7.7 million DNA samples and removing 1.7 million individual profiles (equivalent to suspected individuals in France) and children's profiles from its database. ${ }^{\mathrm{xxi}}$ Returning to France, some opposing arguments are also based on the qualification issued in 2010 by the French Constitutional Council, the body that evaluates the conformity of procedures in regard to the French constitution, which decided that the FNAEG was constitutional, but expressed some reserve, noting that criteria of proportionality should be reintroduced regarding the length of time profiles were retained in the FNAEG database. ${ }^{\text {xii }}$ In June 2017, following a complaint from a farmer who had been convicted of refusing to give a DNA sample after his arrest in connection with a union demonstration, the ECHR, through the famous article 8, unanimously convicted France for the first time in regard to the FNAEG. It invoked a 'disproportionate infringement of his right to respect for private life,' challenging the fact that the law in regard to taking a DNA sample did not differentiate according to the nature and seriousness of the offence committed. ${ }^{\text {xiii }}$ Since the ECHR published this decision, several activists charged with refusing to provide a DNA sample have had their cases dismissed, with magistrates appearing to judge the proportionality of database use in relation to the seriousness of the crime committed on a case by case basis. ${ }^{x i v}$ At the time of writing, an amendment being discussed in the French National Assembly and the Senate would give convicted individuals the same right as suspected individuals to request the removal of their DNA profile from the Public Prosecutor after a period of time prescribed by decree. Moreover, a draft decree relating to the FNAEG, still under debate, would vary the duration of retention based on the seriousness of the offence committed and the age of the offender.

This issue of proportionality, and of private life, is reinforced by the familial nature of DNA. As one activist exclaimed during a trial:

The FNAEG is an intrusion into private life. It's not just my data they have but also that of my parents and my son. You have to understand that! 
During another trial, the partner of an activist called to testify expressed her outrage:

By taking DNA from $\mathrm{Mr}$ [X, her partner], they're also taking the DNA of our children. ..., so in the name of my children, I feel I'm involved in this refusal to be part of the database.

In relation to this issue, for several years familial DNA searches have been developed, providing the ability to search the database for biologically related profiles (parents, children, brothers and sisters) in the absence of an exact profile match. This type of search, which was given a legal basis in 2016, has been used over sixty times in France and has led to the identification of around ten individuals related to a database profile as part of a criminal investigation. Such an approach raises new questions, as indicated by comments from a senior figure in the magistrate union:

During an investigation, a trace of DNA is found . . . and all individuals included in the database, plus potentially their close family through this issue of familial DNA searches, are considered to be suspects.

One senior figure from the LDH further added:

The DNA database has been extended to a criminal's entire family. This poses a problem because you . . . aren't responsible for your brothers, sisters, cousins, etc. . . . It stigmatises families and is absolutely unacceptable.

The perceived 'intimacy' of DNA reveals a particularity of the FNAEG compared to other databases, since genetic information is marked by the duality of being both individual by nature and shared by family groups (Vailly, 2014). This concern in connection with parenthood adds to that formulated in other contexts regarding the use of genetic databases (Machado and Silva, 2016). This characteristic, which classically results from a form of 'genetic exceptionalism' (Murray, 1997), in comparison to other methods of identification such as fingerprints, should come as no surprise if we remember that genetics is defined as 'the science of heredity.' This highlights the fact that the notions of the individual and the collective are an intrinsic part of DNA, as seen here through private and family life. The private life at stake is not only that of the individual activists, but also that of their family collective as a biological entity. In an echo of the political citizenship discussed above, they defend private life as a separation between the public sphere and the family collective. While familial DNA searches have not provoked major public controversy in France in terms of the changing use of the database, it is clear that the jurisdiction effects on (bio)identities criticised by opponents here extend to the biological family ('all the individuals included in the 
database, plus potentially their close family through this issue of familial DNA searches, are considered to be suspects').

In summary, on the one hand it is possible to describe the FNAEG as a database that supports investigations, making it possible to identify DNA profile matches and thus a method that contributes to solving crimes and providing evidence during legal proceedings. On the other hand, it is also possible to describe it as producing 'jurisdiction effects' (Foucault (2001 [1994]a, p. 841). These are the effects that are indirectly contested by opponents. The first resides in the fact that the legal definitions used during proceedings make no distinction between common law offences and those of a union action, political, or community nature. As illustrated by the opening example, this situation is heightened by the fact that it is immaterial whether or not the individual has perpetrated an offence for which DNA profiles are used in an investigation, since DNA profiles are not analysed in order to find graffiti artists. The solving of crimes, which constitutes one of the objectives of the FNAEG, is lost sight of through this delinking of the offence (for which DNA is requested) and the kind of investigation (for which there is no genetic testing). This favours elision between situations of a sufficiently serious nature to justify taking a DNA sample and situations of a less serious nature that do not warrant taking a DNA sample. The second effect resides in the fact that individuals may be convicted for refusing to give a DNA sample despite having been acquitted of the initial offence. Their status thus moves from that of suspect (of the original offence) to that of convicted (for their refusal). In relation to this, we note that between 2004 and 2013, the majority of those convicted of refusing to provide a sample were suspected individuals (63\%, between around 200 and 400 people a year), rarely individuals convicted of a misdemeanour (31\%, between around 100 and 200 people a year) or a felony (6\%, between around 10 and 60 people a year). ${ }^{\mathrm{xxv}}$ In conjunction, the third effect consists of surpassing judicial power through the production of a major category that represents an intermediary group between the innocent and the guilty: individuals who have been arrested and added to the database but not convicted, along with their biological family via familial DNA searches. This broad category is ultimately based on inclusion in the database independent of the legal issue of the offence, since the majority of individuals included in the FNAEG have never been convicted, unlike in some other countries (in Portugal, for example, where suspects are not included in the database). The observation that the concept of the suspected individual as it is understood in criminal cases is changing and transforming into a suspected population (Cole and Lynch, 2006) is here strengthened by the fact that this category represents $75 \%$ of the 
database. ${ }^{\text {xvi }}$ In comparison to other studies of this topic, the French case allows to have a better understanding of oppositions to the file (to consider oneself as a citizen, to dispute the intrusion into the family life, etc.). Moreover, it highlights two points. First, it indicates major consequences for power relationships, as the fact that suspected individuals see their data enter the database and have to appeal to remove it minimises the decision of the legal power that has decided not to convict them (Vailly and Krikorian, 2018). While the legal system has the power to convict or acquit, the police has the power to put and keep non-convicted individuals on file. In these circumstances, the power relationship in regard to the use of genetic databases appears to lean away from the law and towards the police. At the same time, this power relationship is accepted by the majority of the population, which in general consents to the database. Secondly, the French case allows us to make a distinction between two aspects of identity, as we observe not only slippage between offenders and suspects, but also between those acquitted of an offence and convicted of refusing to give a sample. Opponents contest the fact that the identities (in the sense of the 'selfhood') of the categories of perpetrator and suspect, along with their biological families, may merge within the database as both become those of long-term suspects or 'criminals' ( 25 or 40 years depending on the length of time for which the data is retained). They also contest the fact that the identity of opponents can become that of an individual convicted for refusing to give a sample: in all three cases (suspect, convicted as offender or convicted for refusal), individuals are no longer innocent. This strengthens the idea that not only the management of neutral markers is at stake, but also power relationships, the transformation of and slippage between categories, and more generally the formation of the (bio)identities of long-term suspects and convicted individuals.

\section{Veridiction Effects}

The extension of these genetic databanking practices to populations has 'veridiction effects,' or effects regarding what is considered to be true or untrue by the social actors (Foucault, 2001[1994]a, p. 841). This issue will be considered in the following part.

\section{The Circulation of Knowledge}

Defenders of the FNAEG (including senior civil servants, police officers, gendarmes, and the majority of magistrates) maintain that no phenotypic information (regarding disease, physical 
appearance, origin, etc.) can be stored by the FNAEG's database of genetic information or that the information is too fragmented to be used (manuscript in preparation). In addition, they are not publically calling for the use of any medical information that might be provided by DNA to be allowed in police investigations. They thus defend a kind of 'genomic minimalism' (Williams and Johnson, 2004). As we have seen, the law in fact mandates that the markers used are 'non-coding,' further supporting this point. ${ }^{\text {xxvii }}$ Analysing this point of view more generally, while in the medical model suggested by Rabinow (1996), individuals carry a genetic modification that directly contributes to the onset of a disease, here 'non-coding' DNA constitutes only a tracer that claims to be neutral, like DNA profiles. In this sense, the relationship between biological life and social life (Vailly, Kehr and Niewöhner, 2011), which constitutes 'bio-identity' (Rabinow, 1996), is not of the same kind: it is explanatory in Rabinow's medical model (the 'mutation' indicates predisposition to a disease), and correlative in the security model outlined here (the 'marker' serves to trace identity). And yet, some people who oppose the database - or their institutional backers (SM, SAF, LDH) argue that the DNA data used by the FNAEG may hold information other than identifying information. The very nature of the markers is in question.

How did this argument arise, and what have been its effects? The question of the information held or not held by DNA markers in the FNAEG emerged at the instigation of an activist opposed to the extensive use of advertising billboards. Confronted with the demand for a DNA sample and unsure about the 'non-coding' nature of the markers, he searched the internet for information on this topic. His attention was drawn to a press release promoting a scientific paper, with no connection to the FNAEG, which showed a link between non-coding DNA segments and a genetic disorder (Pierre Robin syndrome). This suggested more broadly that the non-coding character of DNA sequences did not mean they could provide no individual information. Wanting to know more, the activist contacted a genetic researcher, who looked more specifically at the markers in the FNAEG. This geneticist explained in an interview the link between the populational dimension of the database and the information collected:

Once you have a large database, you need a lot of [genetic] markers, otherwise there is a risk of confusing two people. And as soon as you have a lot of markers, you have information.

What kind of information? This geneticist identified an Italian study that showed that one of the markers used in the FNAEG (D2S13-38) might be associated with genetic predisposition 
to a rare disease (pseudohyperkalaemia) (Carella at al., 2004), as well as a Chinese study suggesting that another marker also used in the FNAEG (D2S1S11-38) might be associated with an increased risk of coronary disease (Hui et al., 2011). Nonetheless, since associations between different markers (not included in the FNAEG) and predispositions to disease are regularly published in the scientific literature, it is possible that new associations between genetic markers that are included in the FNAEG and predispositions to disease may be described in future. In addition, this geneticist found a paper indicating that it might be possible to obtain some information about an individual's geographic origin from the 17 markers in the FNAEG, which are also the markers most used internationally. ${ }^{\text {xxviii }}$ This Portuguese study stated that: 'The accuracy of individual population affiliation is approximately $86 \%$, showing that the common set of STRs ${ }^{\mathrm{xxix}}$ routinely used in forensics provide a considerable amount of information for population assignment, in addition to being excellent for individual identification' (Pereira Luisa et al., 2011, p. 630). Furthermore, these Portuguese researchers had set up a program called PopAffiliator (short for Population Affiliator), which was freely accessible online and allows information on an individual's origin to be obtained from their DNA. The information available would, however, be relatively broad - by continent: Eurasia, East Asia, sub-Saharian Africa - since the markers were not chosen to distinguish between populations. Yet until now, 'ethnic' or 'racial' categories have been entirely absent from the FNAEG, unlike in the British equivalent, for example. ${ }^{\mathrm{xx}}$ In France, if the criminality/genetics/databanking/so-called ethnic origin combination were to be proved, this would effectively render the database illegal within the country and make it highly controversial. ${ }^{\text {xxxi }}$

This French geneticist was already a member of an association advocating the civic responsibilities of people working in research, and has since testified during legal proceedings against several activists who have refused DNA samples, outlining the information (regarding predisposition to illness and origin) that may be detectable from DNA markers. She has been in contact with lawyers on this subject, and some have gradually taken up the argument. The following remarks from a lawyer during a trial for refusing a DNA sample demonstrate how the argument may be presented:

Madame [X], a researcher at INSERM and a doctor of genetics and statistics. . has said some very interesting things about the FNAEG, for example that the samples of DNA that can be taken now allow us to find out. . geographic origins, ethnic origins, and some medical information. And yet article 704-55 of the Penal Procedure Code 
authorises only the taking of non-coding DNA segments. So now the information they hold, the information that can be extracted from a strand of DNA, is illegal! Illegal, because this information is not neutral, it speaks to us... Now. . the barrier established by the legislator saying, 'It is not possible to go further than can be decrypted,' this barrier no longer exists! This is in breach of the original agreement!

During another trial, the partner of an activist called to testify expressed with outrage:

We know that DNA codes a lot more than they say, it says more than they think, so... I feel I am involved in this refusal to be part of the database.

She thus establishes the idea of markers that can 'speak,' based on the scientific arguments circulating in activist circles. For the activists at the forefront of the subject, the proof is there, it has been published in academic journals. From this point of view, taking DNA profiles creates new categories of individuals by continent. In addition, genetic technology produces forms of knowledge through DNA markers that are even more informative because they belong to a large database ('once you have a large database, you need a lot of markers. . . And as soon as you have a lot of markers, you have information'). The coverage of large populations conditions the level of information provided by DNA profiles, which in return may enable not only the identification of individuals, but also their characterisation. Again, the identity of individuals here at stake appears to go beyond the context of comparing DNA profiles (in the register of sameness) and extend to the register of characterising individuals (based on their predisposition to a disease or their origin, in the register of selfhood), but this time based on scientific arguments.

\section{Between Science and the Law}

The argument surrounding the information held or not held by DNA samples has been judged sufficiently serious for the lawyers engaged by defenders to ask for formal rulings through the Questions Prioritaires de Constitutionalité or QPC. The QPC offers the opportunity for every citizen, during a trial, to challenge a law that they believe does not conform to the French Constitution. There is insufficient space here to detail the different paths and stages of these QPC, so we will simply note the principal arguments of the tribunals that have decided on their admissibility and adjudged that the taking of DNA profiles conforms to the Constitution. ${ }^{\text {xxii }}$ This decision rests principally on the illegality of using this information on individuals even if it is indeed available: 'Neither the arrangements contested, nor the resulting information stored by the FNAEG, authorise the analysis of individuals' genetic 
characteristics. . . but only their identification by means of this genetic material.' ${ }^{x x x i i i}$ Yet, according to the lawyer involved in this particular case:

[According] to the legislative boundaries. .., it should be a question of not being able to examine the phenotypic information if anyone ever wanted to alter use of this database. . One of the safeguards put in place was that the databases contained only non-coding segments, in order to make it impossible to do anything other than simply identify an individual. And this is not the case.

In short, this lawyer insists not only on the prohibition against using an individual's phenotypic information, but above all on the impossibility of doing so, in the spirit of the law that foregrounded the importance of 'non-coding' precisely for this reason. In an interview this lawyer adds a further argument surrounding the political context of the rise of extreme right-wing ideas, and the potential political use of this information:

They're going to hold this data for 50 years, and who knows what will be happening in France in 50 years' time? I just don't know, I don't know, [leader of an extreme rightwing party] is on the up, I just don't know. So maybe these files that hold data on millions of people could eventually be used to find out the geographic origin of people, we just don't know.

Sometimes in connection with the scientific arguments regarding origin discussed above, these opponents establish a link between France's history, the dark days of World War II and its files of information on Jews, and its possible future, in the context of the recent electoral success of the extreme right. They observe that when Jews were rounded up during the war, perforated index cards were used by the police in order to optimise classification, filing, and efficiency. One explains in an interview:

When they create population databases, particularly of the political population like us, of dissidents, we can see it beginning, but we don't know where it will end . . They put people in wagons [reference to World War II].

Some of these protestors have personal experience to support this comparison, notably one whose grandfather added the names of Jews to a filing index during the war and lived with their death on his conscience. These concerns are not however limited to statements made in sociology interviews or activists' trials but are also sometimes expressed in the mainstream press, as in these extracts from the national written media:

This use of genetic databases may be extremely dangerous. When Jews were asked to register as Jewish under the Vichy regime, they told themselves they had nothing to 
hide and had to comply. But they ended up in Nazi concentration camps. A change of government or policy may happen at any time. ${ }^{\text {xxiv }}$

It stigmatises a category of the population just like during the Vichy period, when the government drew up databases of deviant populations. ${ }^{\mathrm{xxx}}$

Other opponents insist:

If the extreme right came to power tomorrow, they could use these databases however they like. Until recently, it was thought that this database did not allow individuals to be distinguished based on their origins, but geneticist X. . . has shown that this is not the case. ${ }^{\mathrm{xxxvi}}$

Certain concerns about the misuse of genetic data formulated in other countries around a lack of confidence in institutions (Machado and Silva, 2016; Teodorovic et al., 2017), find particular resonance here due to their political context.

The different QPC admissibility judgments have answered that the question posed was technical and that it was not their role to get involved. Another argument presented by the Court of Cassation is that it is the responsibility of the regulatory authorities rather than the judiciary to decree a change in the number and nature of the segments used in DNA analysis as scientific understanding evolves. ${ }^{\text {xxvii }}$ Moreover, the technical nature of this argument on the possible information held by the DNA samples has other repercussions since it limits its use by opponents and their lawyers.

Firstly, opponents thus assert scientific arguments that it is not only no longer impossible to provide information by taking DNA profiles, notably with continent categories, but that this may be subject to simple interdiction, and is likely one day to be reconsidered. Secondly, the potential political use of the database constitutes another key issue for these opponents. This confirms anew the idea that studying genetic markers for studying the origin of individuals is 'lending renewed authority to biological conceptions of human difference and providing fodder for national debates over belonging, self-definition, and political power' (Wailoo, Nelson and Lee, 2012, p. 2). Unlike in the United States (Etzioni, 2004), there have been no instances to date in France of DNA information being abused by employers to dismiss people from certain jobs. This contributes to the fact that the employment-related argument is not one of those used by opponents, who focus instead on the risk of the political use of databases, as occurred during World War II. In fact, as in the case of DNA analysis conducted in order to find out the geographic origin of suspects (Vailly, 2017), World War II and the historical 
context of collaboration between French 'collabos' and the Nazi regime, seem to be clear factors in understanding the way in which the FNAEG is problematised in France. These opponents seek to introduce a form of citizen control that would effectively operate on the link between genetic technology and the potential biopolitical use of identity ('so maybe these files that hold data on millions of people could eventually be used to find out the geographic origin of people'). To our knowledge, it is the first time that this issue of the information provided by the markers used in forensic science has been posed in such a direct manner in a public debate. Unlike other studies of forensic genetics, which highlight the separation between scientific and lay knowledge (including Williams and Wienroth, 2014b), or concerns around use of information by the state rather than the intrinsic properties of DNA (Williams and Johnson, 2004), our study demonstrates not only an appropriation of knowledge by lay individuals, but also the driving role of citizens in promoting these new debates based on scientific arguments. However, as we have seen, these remain relatively limited due to their technical nature.

\section{Conclusion}

The use of DNA databases by the police and judicial system has risen sharply over the last twenty years (Hindmarsh and Prainsack, 2010). Their development has fed (and been fed by) the growth of genetic and computing technologies (Atkinson, Glasner and Lock, 2009; Mattelart and Vitalis, 2014) in tandem with the heightened profile of security issues in public opinion and policy, particularly in relation to the terrorist threat (Robert and Pottier, 2004). This has been reflected in the expansion of DNA databases to whole populations, including in France. The use of the DNA database in France is more extensive than in other countries (Lazer, 2004; Hindmarch and Prainsak, 2010), since it includes minors and those who have been suspects, and covers a broad range of offences. In this context, we have analysed, from the point of view of the opponents of DNA databases, the role played by the social practices of genetics in a policing and legal context in producing the (bio)identities attributed to (or claimed by) individuals, and the effects of these processes in legal and scientific spheres.

Firstly, we have highlighted that opposition is not expressed in relation to an approach targeting dangerous individuals, but to one focused on a population: opponents distinguish between comparing the DNA of a specific individual as part of a specific investigation with a trace found at a crime scene, and holding data on millions of individuals. In relation to this 
shift and based on the work of Ricœur (1992), we have shown that one of the key points of opposition concerns the transformation of the (bio)identity of individuals ('it's like suspecting these millions of French people of being possible offenders'). According to opponents, this now goes beyond the context of comparing DNA profiles (in the register of sameness) and extends to the register of long-term suspicion (where individuals become suspects on file for 25 years, in the register of selfhood) or the characterisation of individuals (depending on their predisposition to a disease or their origin, also in the register of selfhood). This transformation has two features: 1) while the specific comparison of DNA profiles demonstrates the uniqueness of individuals, long-term suspicion or the characterisation of individuals makes them members of a collective (perpetrators of an offence or suspects on file, or part of categories such as 'origin'); 2) while the specific comparison of DNA profiles demonstrates the permanence of biological identity, the use of expanded databases produces identities that are not permanent, but may shift between innocent, suspected or guilty. In summary, by adapting concepts of sameness and selfhood originally attributed to the 'self' (Ricœur, 1992) to both the 'other' (the individual perceived as an offender) and the 'self' (the individual who sees himself or herself as a citizen), we are able to distinguish between two overlapping aspects of (bio)identity that have not previously been highlighted. Furthermore, while our data confirm the as-yet exploratory intuition of Rabinow and his colleagues regarding 'something called biosecurity' (Collier, Lakoff and Rabinow, 2004, p. 5), they make it possible to go further by demonstrating the truly political issues of bio-identity: the bio-identity attributed to the other and to the self within a form of knowledge/power.

Next, we have shown, following Foucault (2001[1994]a, p. 841), that when applied to populations these practices produce 'jurisdiction effects' that feed opposition. These effects are seen : 1) in the elision between situations of a sufficiently serious nature to justify taking a DNA sample and situations of a less serious nature that do not warrant taking a DNA sample; 2) in the fact that individuals may be convicted for refusing to give a sample after being acquitted of an original offence; 3) in the production of a major category constituting an intermediary group between the innocent and the guilty: individuals who have been arrested and added to the database but not convicted. This indicates a biopolitics that is both penal and police-focused: penal (implementing the judicial approach) because it leads individuals acquitted for an original offence to be convicted for refusing to give a sample; and policefocused (surpassing the judicial approach) because the FNAEG not only includes individuals who are recognised as criminally guilty under the law, but also those who may be of interest 
to the police due to their previous behaviour. As we have shown, this has major consequences in terms of power relationships: while the legal system has the power to convict or acquit, the police has the power to put and keep non-convicted individuals on file. In these circumstances, the power relationship in regard to genetic databases appears to lean away from the law and towards the police. Furthermore, the majority acceptance of the extended database among the French population makes it possible to conceive of situations linked to power relationships that do not boil down to imposed surveillance (Machado and Silva 2016, Prainsack and Toom, 2010).

Lastly, these practices have 'veridiction effects' (Foucault 2001[1994]a, p. 841). Some opponents to DNA profiling raise scientific arguments based on the information that might be provided by the FNAEG regarding origin and rare diseases, although this was not its original goal. This information is made available, according to the geneticist who supports their mobilisation, by the very fact of the extension of the database (the larger the population, the more markers required to identify individuals, and the more markers that are analysed, the more information is made available). In other words, in an echo of extending databases to population-level, these techniques establish probabilities based on statistical calculations that generate new resistance of a scientific nature. In this way, the guarantees around the database seem even less secure in the eyes of opponents. They believe that use of the information that can be taken from DNA is particularly sensitive in two respects: 1) in terms of the family collective which, by definition, shares genetic data; 2) in terms of potential biopolitical use of identity by an authoritarian government. To paraphrase the Attorney General Reno (Jasanoff, 2004, p. 342), these opponents take a position in which 'the challenge is to learn how to govern, rather than be governed by, the power of DNA.' They view the coexistence of security consciousness and the rise of technology as being dangerously linked to a technological capacity to respond to aspirations for political control, setting us on a slippery slope towards authoritarianism in a relatively near future. This final point enables us to situate these debates in the French context, which is marked by the history of World War II and the files of information held on Jews, and the recent electoral success of the extreme right. Beyond its results, our work points to the potential value of continuing the study of the way in which scientific data, which are socially performative, transform social categories, and of the issues surrounding the protection of personal data gathered by the private sector.

\section{References:}


Aas, K.F. (2006) 'The body does not lie': Identity, risk and trust in technoculture. Crime, media, culture 2(2): 143-158.

Agamben, G. (1998 [1995]) Homo Sacer: Sovereign Power and Bare Life. Stanford: Stanford University Press.

Atkinson, P., Glasner, P. and Lock, M. (2009) Handbook of Genetics and Society. Mapping the New Genomic Era. New York: Routledge.

Becker, H.S. (1973) Outsiders: Studies in the Sociology of Deviance. New York: The Free Press.

Bonneuil, C., Joly, P.B. and Marris, C. (2008) Disentrenching experiment. The construction of GM-Crop field trials as a social problem. Science, Technology \& Human Values. 33(2): 201-229.

Bowker, G.C. and Star, S.L. (2000) Sorting Things Out. Classification and its Consequences. Cambridge, London: The MIT Press.

Carella M. et al. (2004) A second locus mapping to 2q35-36 for familial pseudohyperkalaemia. European Journal of Human Genetics 12: 1073-1076.

Castel, R. (1981) La gestion des risques: de l'anti-psychiatrie à l'après-psychanalyse. Paris: Les Editions de Minuit.

Cole, S.A. and Lynch, M. (2006) The social and legal construction of suspects. Annual Review of Law and Social Science 2: 39-60.

Collier, S, Lakoff, A. and Rabinow, P. (2004) Biosecurity: Towards an anthropology of the contemporary. Anthropology Today 20(5): 5-7.

Curtis, C. (2014) Public understandings of the forensic use of DNA: Positivity, misunderstandings and cultural concerns. Bulletin of Science, Technology \& Society 34(12): 21-32.

Etzioni, A. (2004) DNA Tests and databases in criminal justice: Individual rights and the common good. In: D. Lazer (ed.) DNA and the Criminal Justice System. The Technology of Justice. Cambridge, London: The MIT Press, pp.197-223.

Foucault, M. (1982) The subject and power. In: H. Dreyfus and P. Rabinow (eds.). Michel Foucault: Between Structuralism and Hermeneutics. Chicago: Chicago University Press, pp. 208-226.

Foucault, M. (2001 [1994]a) Dits et écrits II, 1976-1988. Paris: Gallimard.

Foucault (2001 [1994]b) Dits et écrits I, 1954-1975. Paris: Gallimard. 
Gamero, J.J., Romero, J.M., Peralta, J.L. et al. (2004) DNA technology application procedures in forensic practice: Social and ethical conditioning II. International Congress Series 1261: 571- 573.

Glaser, B.G. and Strauss, A. (1967) The Discovery of Grounded Theory. London: Aldine.

Guillen, M, Lareu, M.V., Pestoni, P., et al. (2000) Ethical-legal problems of DNA databases in criminal investigation. Journal of Medical Ethics 26: 266-271.

Hacking, I. (2005) Seminar « Façonner les gens ». Collège de France, Paris.

Heinemann, T. and Lemke, T. (2014) Biological citizenship reconsidered. Science, Technology \& Human Values 39(4): 488-510.

Hindmarsh, R. (2010) Biosurveillance and biocivic concerns, from 'truth' to 'trust': the Australian forensic DNA terrain. In: R. Hindmarsh and B. Prainsack (eds.) Genetic Suspects. Global Governance of Forensic DNA Profiling and Databasing. Cambridge: Cambridge University Press, pp. 262-287.

Hindmarsh, R. and Prainsack, B. (eds.) (2010) Genetic Suspects. Global Governance of Forensic DNA Profiling and Databasing. Cambridge: Cambridge University Press.

Hui, L., Jing, Y. and Weijian, Y. (2011) Novel association analysis between 9 short tandem repeat loci polymorphisms and coronary heart disease based on a cross-validation design. Atherosclerosis 218: 151-155.

Jasanoff, S. (2004) DNA's Identity crisis. In: D. Lazer (ed.) DNA and the Criminal Justice System. The Technology of Justice. Cambridge: MIT Press, 337-355.

Jenkins, R. (2000) Categorization: Identity, social process and epistemology. Current Sociology 48(3): 7-25.

Keck, F. (2010) Note sur le texte de P. Rabinow. Biosocialité : genèse, enjeux et postérité d'un concept. Politix 2(90): 21-46.

Koch L. and Stemerding, D. (1994) The sociology of entrenchment: A cystic fibrosis test for everyone? Social Science \& Medicine 39 (9): 1211-1220.

Lazer, D. and Meyer, M.N. (2004) DNA and the criminal justice system: Consensus and debate. In: D. Lazer (ed.) DNA and the Criminal Justice System. The Technology of Justice. Cambridge: MIT Press, pp. 357-390.

Lianos, M. (2003), Le contrôle social après Foucault. Surveillance \& Society 1(3): 431-44.

Machado, H. and Silva, S. (2009) Informed consent in forensic DNA databases: Volunteering, constructions of risk and identity categorization. BioSocieties 4: 335-348. 
Machado, H. and Silva, S. (2014) "Would you accept having your DNA profile inserted in the national forensic DNA database? Why?" Results of a questionnaire applied in Portugal. Forensic Science International 8: 132-136.

Machado, H. and Silva, S. (2016) Voluntary participation in forensic DNA databases: Altruism, resistance, and stigma. Science, Technology \& Human Values 41(2): 322-343.

Mattelart, A. and Vitalis, A. (2014) Le profilage des populations. Du livret ouvrier au cybercontrôle. Paris: La Découverte.

Marx, G.T. (2015) Surveillance Studies, International Encyclopedia of the Social \& Behavioral Sciences. Second Edition, 733-741.

Murray, T. (1997) Genetic exceptionalism and future diaries: Is genetic information different from other medical information? In: M.A. Rothstein (ed.) Genetic Secrets. Protecting Privacy and Confidentiality. New Haven: Yale University Press, pp. 60-73.

Pereira, L. et al. (2011) PopAffiliator: Online calculator for individual affiliation to a major population group based on 17 autosomal short tandem repeat genotype profile. International Journal of Legal Medicine 125: 629-636.

Petryna, A. (2002) Life Exposed: Biological Citizens after Chernobyl. Princeton: Princeton University Press.

Prainsack, B. and Toom, V. (2010) The Prüm régime. Situated dis/empowerment in transnational DNA profile exchange. British Journal of Criminology 50(6): 1117-1135.

Rabinow, P. (1996) Essays on the Anthropology of Reason. Princeton: Princeton University Press.

Rapport d'information sur les fichiers mis à la disposition des forces de sécurité [Fact-finding report on databases available to the security forces] (2018), presented by the elected representatives Didier Paris and Pierre Morel-A-l'Huissier, French National Assembly, 17 October 2018.

Ricœur, P. (1992) Oneself and Another. Chicago: Chicago University Press.

Robert, P. and Pottier, M.-L. (2004) Les préoccupations sécuritaires : une mutation ? Revue française de sociologie 45(2): 211-241.

Rose, N. (2007) The Politics of Life Itself. Biomedicine, Power and Subjectivity in the Twentyfirst Century. Princeton: Princeton University Press.

Schramm, K., Skinner, D. and Rottenburg, R. (2012) Identity Politics and the New Genetics. New York: Berghahn.

Skinner, D. (2011) Mobile identities and fixed categories. Forensic DNA and the politics of racialized data. In: R. Rottenburg, K. Schramm and D. Skinner (eds.) Identity Politics 
After DNA: Re/creating Categories of Difference and Belonging. Oxford: Berghahn Books, pp. 53-78.

Teodorovic, S., Mijovic, D., Radovanovic Nenadic, U. and Savic, M. (2017) Attitudes regarding the national forensic DNA database: Survey data from the general public, prison inmates and prosecutors'offices in the Republic of Serbia. Forensic Science International 28: 44-51.

Tutton, R. and Levitt, M. (2010) Health and wealth, law and order: banking DNA against disease and crime. In: R. Hindmarsh and B. Prainsack (eds.) Genetic Suspects. Global Governance of Forensic DNA Profiling and Databasing. Cambridge: Cambridge University Press, pp. 85-104.

Vailly, J. (2013) The Birth of a Genetics Policy. Social Issues of Newborn Screening. New York: Routledge.

Vailly, J. (2014) Genetics. In: W.C. Cockerham, R. Dingwall and S. Quah (eds.) The WileyBlackwell Encyclopaedia of Health, Illness, Behavior, and Society. Oxford: WileyBlackwell, vol. 2, pp. 661-665.

Vailly, J. (2017) The politics of suspects' geo-genetic origin in France: The conditions, expression, and effects of problematisation. BioSocieties 12(1): 66-88 (on-line 18 October 2016).

Vailly, J., Bellivier, F., Noiville, C., and Rabeharisoa, V. (2016) Les fichiers d'empreintes génétiques et les analyses d'ADN en droit pénal sous le regard du droit et de la sociologie. Cahiers Droits, Sciences \& Technologies 6: 43-53.

Vailly, J., Kehr, J. and Niewöhner, J. (eds.) (2011) De la vie biologique à la vie sociale. Approches sociologiques et anthropologiques. Paris: La Découverte.

Vailly, J. and Krikorian, G. (2018) Durabilité et extension du soupçon. Catégorisations et usages policiers du fichier d'empreintes génétiques en France. Revue française de sociologie 59(4): 707-733 (English version forthcoming).

Veth, J.S. and Midgley, G. (2010) Finding the balance: forensic DNA profiling in New Zealand. In: R. Hindmarsh and B. Prainsack (eds.) Genetic Suspects. Global Governance of Forensic DNA Profiling and Databasing. Cambridge: Cambridge University Press, pp. 288-308.

Wailoo, K., Nelson, A. and Lee, C. (eds.) (2012) Genetics and the Unsettled Past: The Collision of DNA, Race, and History. Piscataway: Rutgers University Press.

Williams, R. and Johnson, P. (2004) 'Wonderment and dread': Representations of DNA in ethical disputes about forensic databases. New Genetics \& Society 23(2): 205-223. 
Williams, R. and Johnson, P. (2005) Inclusiveness, effectiveness, and intrusiveness: Issues in the developing uses of DNA profiling in support of criminal Investigations. Journal Law Med. Ethics 33(3): 545-558.

Williams, R. and Wienroth, M. (2014a) Public perspectives on established and emerging forensic genetics technologies in Europe. EUROFOGEN-NoE.

Williams, R. and Wienroth, M. (2014b) Identity, mass fatality and forensic genetics. New Genetics and Society 33(3): 257-276.

Williams, R. and Wienroth, M. (2017) Social and ethical aspects of forensic genetics: A critical review. Forensic Science Review 29: 145.

Wilson-Kovacs, D., Wyatt, D. and Hauskeller, C. (2012) “A Faustian bargain?” Public voices on forensic DNA technologies and the National DNA Database. New Genetics and Society 31(3): 285-298.

\footnotetext{
${ }^{\mathrm{i}}$ The Traitement d'Antécédents Judiciaires or Judicial History Application (TAJ) is the widest and most commonly used database. At the end of March 2016, the TAJ included 15.6 million files on suspected individuals (cf. Report of the Court of Auditors, 15 February 2017). As for the French fingerprint database, the Fichier automatisé des empreintes digitales (FAED), in October 2018 it included 6.2 million registered individuals and 220,000 traces (cf. Rapport d'information sur les fichiers mis à la disposition des forces de sécurité, 2018).

${ }^{\text {ii }}$ Article 706-55 of the Penal Procedure Code (Code de Procédure Pénale).

iii The law describes 'serious or corresponding evidence' making it 'probable' that the individuals have committed an offence covered under the scope of the FNAEG (article 706-54 paragraph 2 of the Penal Procedure Code).

${ }^{\text {iv }}$ Cf. Questions to the Government no. 68468, 12 January 2010, Response of 6 April 2010; no. 6423, 9 October 2012, Response of 12 February 2013; no. 40427, 22 October 2013, Response of 5 August 2014; no.79728, 19 May 2015, Response of 8 December 2015. According to a senior civil servant from the Ministry of Justice, these figures are questionable since individuals enter the database as suspects, and their file is not always updated when they are convicted. However, the overwhelming majority of individuals in the database have not been convicted.

${ }^{v}$ Circular of 9 July 2008 from the Ministry of Justice CRIM-PJ no. 08-28.H5. According to this circular, 'regarding minors over the age of 13 , the advisability of taking a sample must be carefully assessed, following consultation between the judicial police and the prosecution service.'

${ }^{v i}$ Personal communication from the forensic science department of the police services.

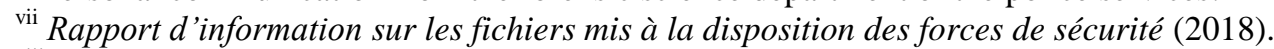

viii Article 706-54 of the Penal Procedure Code.

${ }^{\text {ix }}$ Source: personal communication from a senior civil servant in the Ministry of Justice.

${ }^{x}$ Article 706-54 of the Penal Procedure Code.

${ }^{x i}$ The types of genetic markers used for DNA fingerprints are called Short Tandem Repeats (STR). As the name suggests, they are short sequences of repeated DNA that experts distinguish by size.

xii The practices and discourses of police officers and gendarmes have been analysed in another study (Vailly and Krikorian, 2018).

xiii The law of 18 March 2003 regarding internal security made the refusal to give a DNA sample an offence that carries a maximum penalty of 15,000 euros and a 1 year prison sentence for suspected individuals, to be doubled in the case of convicted individuals.

${ }^{\text {xiv }}$ Circulars of 27 July 2004 and 9 July 2008 from the French Ministry of Justice CRIM-PJ nº8-28.H5.

${ }^{\mathrm{xv}}$ Statistics provided by the Ministry of Justice.

${ }^{x v i}$ This confirms that the easier a system of categorisation is to use, and the broader it is (here spanning innocent, suspected and guilty individuals), the less visible it is (Bowker and Star, 2000).

xvii This lawyer uses the term 'whistleblowers' for opponents who alert public opinion to what they consider to be a danger or a problem (police use of databases, advertising, GM crops, etc.).
} 
xviii While emphasising that this argument was seldom used during our interviews, it should be noted that the larger the database, the more likely comparison errors (false positive matches) between a trace and a suspect are to occur. This means that individuals in a database are more likely than individuals not in a database to be victims of a false positive match.

${ }^{x i x}$ Borrowing the term used by Petryna (2002) to describe people exposed to radiation from Chernobyl, Rose (2007) talks about a 'biological citizenship' encompassing projects that are led by citizens and linked to their biological existence as human beings. Due to the dimension of choice and responsibility of actors expressed by this concept, it primarily applies in a medical context (prenatal testing, etc.).

${ }^{\mathrm{xx}}$ There are two points to note here: 1) In the S. and Marper v The United Kingdom case, the court held that the blanket and indiscriminate retention of DNA profiles and the samples of suspected individuals-as was the case in the UK until the ECHR's judgment-was, in the context of state intrusion into the private life of an individual, in contradiction with the need for proportionality between an offence committed and the request for a DNA sample (we recall that the DNA samples of identified individuals, in France, are not retained). Case of S. and Marper v. The United Kingdom. Judgment of 4 December 2008. Accessed July 242016.

https://www.coe.int/t/dghl/standardsetting/dataprotection/Judgments/S.\%20AND\%20MARPER\%20c.\%20ROY AUME\%20UNI\%20fr.pdf; and 2) These opponents also base their arguments on the 2013 condemnation of France by the ECHR with regard to its physical fingerprint database (the Fichier Automatisé des Empreintes Digitales or FAED) in a way which could be transposed to the FNAEG, and this conviction rested on the concept of proportionality and private life in exactly the same terms as those of the Marper judgment. Case of M.K. v France. Judgment of 18 July 2013. Several organisations, including the SM, the LDH and the SAF, also questioned the Ministry of Justice in this regard in 2013.

${ }_{\mathrm{xxi}}$ National DNA database strategy Report. Annual Report. 2013-2014 Home Office. Cf. https://www.gov.uk/government/publications/national-dna-database-annual-report-2013-to-2014 accessed 9 October 2017.

${ }^{x x i i}$ QPC decision n²010-25 of 16 September 2010.

xxiii CEDH 2015 press release of 22 June 2017 (http://hudoc.echr.coe.int/eng-press\#\{\%22itemid\%22:[\%220035758132-7319608\%22]\} accessed 22 August 2017).

xxiv 'Fichage génétique: la France toujours dans l'illégalité', Jérôme Hourdeaux, Mediapart, 20 April 2018.

xxv Statistics provided by the Ministry of Justice (2003-2013).

${ }^{x x v i}$ Incidentally, while there is a high proportion of convictions for refusing to give a sample, sentences are generally light. They usually consist of fines or suspended sentences, or sometimes adjusted sentences, since judges quite clearly treat individuals who refuse a DNA sample differently when they are convicted for a sexual crime compared to a minor offence. Although judges apply the law strictly, the rather symbolic nature of some penalties (100 euros) indicates that they may not be entirely at ease with these borderline cases, particularly where the original charge has been dropped but the charge against the DNA refusal pursued.

xxvii Article 706-54 (Paragraph 5) of the Penal Procedure Code.

xxviii Since August 2018, the numbers of markers studied has been fixed at 21 as per the Decree of 10 August 2015-art. 2(V).

xxix See note xi.

xxx Through a study of the United Kingdom's genetic database, Skinner (2011) reveals a policy centred on the construction and use of racial data, demonstrating the recurrent discussion of the validity and legitimacy of the use of so-called ethnic or racial categories.

${ }^{x x x i}$ For a study of the sensitivity of this topic and its legal context in France, in regard to other practices involving the police and legal system, see (Vailly, 2017).

xxxii See the following judgments for details: Jugement du Tribunal de Grande Instance de Senlis du 21 mars 2012, Arrêt de la Cour de cassation du 19 juin 2012, Jugement en Appel du Tribunal de Grande Instance de Senlis du 26 novembre 2012, Jugement de la Cour d'Appel d'Amiens du 13 juin 2014, Arrêt de la Cour de cassation du 10 juin 2015.

${ }^{\text {xxxiii }}$ See the judgment Arrêt de la Cour de cassation du 10 juin 2015.

xxxiv 'Ils ont refusé de donner leur ADN', Louise Fessard, Mediapart, 19 September 2011.

xxxv 'Les apprentis sorciers du fichage ethnique', Anonymous, L'Express, 28 March 2007.

xxxvi 'Ils ont refusé de donner leur ADN', Louise Fessard, Mediapart, 19 September 2011.

xxxvii The Oversight Committee and the Interministerial Committee responsible for the FNAEG (Vailly and Krikorian, 2018) have not produced their own public reports on these issues.

\section{Aknowledgements:}


This research benefited from funding from the French National Research Agency (contract: ANR-14-CE29-0014, Project "Fichiers et témoins génétiques: généalogie, enjeux sociaux, circulation", acronym FiTeGe, coordinator: Joëlle Vailly). This text was translated by Cadenza. 